\title{
Kepemilikan Manajerial dan Praktik Penghindaran Pajak
}

Studi pada Perusahaan Manufaktur terdaftar di BEI Periode Tahun 2015-2017

\author{
Nanik Niandari \\ Akademi Akuntansi YKPN \\ Yogyakarta, Indonesia \\ niandarinanik@gmail.com
}

\author{
Rachmawaty Hanny Yustrianthe \\ Akademi Akuntansi YKPN \\ Yogyakarta, Indonesia \\ rahmahanny@gmail.com
}

\section{Evi Grediani \\ Akademi Akuntansi YKPN \\ Yogyakarta, Indonesia \\ gredianie@gmail.com}

Corresponding Author : Nanik Niandari

Submitted: 14 Juni 2020

Accepted: 2 Agustus 2020

Published: 2 Agustus 2020

\section{ABSTRAK}

This study test the effect of managerial ownership on propensity of tax avoidance behaviour. Data used in this study were obtained from Indonesian stock exchange database and company's annual report. The author uses regression analysis with unbalanced panel data types from a sample of 144 manufacturing companies covering years period of 2015 to 2017. Propensity of tax avoidance as a dependent variable is measured by effective tax rate (ETR). The independent variable is managerial ownership which is determined by 2 (two) types of measurements. First measurement use a percentage form, and second measurement use a dummy based on the level of managerial ownership. The control variables used include return on assets (ROA), company size and leverage. We find that managerial ownership has a positive effect on propensity of tax avoidance. Another finding in this study is that the effect of managerial ownership on propensity of tax avoidance occurred at managerial ownership levels of less than 20\%. The results of this study are expected to contribute the literature study of managerial ownership towards propensity of tax avoidance.

Keywords : Agresivitas Pajak, Effective Tax Rate (ETR), Kepemilikan Manajerial, Penghindaran Pajak, Tax Avoidance

\section{PENDAHULUAN}

Praktik penghindaran pajak menjadi fokus perhatian pemerintah karena pajak menjadi sumber pendapatan utama bagi negara. Bagi para akademisi, kajian ilmiah terkait penghindaran pajak masih menjadi topik yang menarik untuk diteliti. Karakteristik pajak menciptakan konflik kepentingan diantara stakeholder perusahaan yakni pemegang saham (shareholder) dan pemerintah. Pajak bagi pemerintah merupakan pendapatan yang

This is an Creative Commons License This work is licensed under a

Creative Commons Attribution-NonCommercial 4.0 International

License. 
diharapkan pencapaiannya maksimal. Bagi pemegang saham, pajak merupakan beban yang harus dibayar oleh perusahaan. Pembayaran pajak perusahaan akan mempengaruhi jumlah laba yang tersedia untuk pemegang saham.

Penelitian terkait penghindaran pajak mencoba menguji pengaruh struktur kepemilikan terhadap perilaku penghindaran pajak (tax avoidance). Hasil penelitian menunjukkan hasil yang masih belum konsisten. Penelitian Fadhila, Pratomo, \& Yudowati (2017), Boussaidi \& Hamed (2015) serta Badertscher, Katz, \& Rego (2013) menunjukkan bahwa kepemilikan managerial (managerial ownership) berhubungan negatif dengan penghindaran pajak. Penelitian lain yang dilakukan oleh Zhou (2011), Cabello, Gaio, \& Watrin (2019), Multazam (2018), serta Chan, Mo, \& Zhou (2013) menunjukkan hasil yang berbeda bahwa kepemilikan manajerial memiliki pengaruh positif terhadap penghindaran pajak. Hasil lainnya oleh Jamei (2017) serta Prasetyo dan Pramuka (2018) menunjukkan bahwa kepemilikan manajerial tidak memiliki pengaruh terhadap penghindaran pajak.

Penelitian ini bertujuan untuk menguji pengaruh kepemilikan manajerial terhadap kecenderungan penghindaran pajak (propensity of tax avoidance). Penelitian dilakukan untuk menambah literatur tentang pengaruh kepemilikan manajerial terhadap penghindaran pajak yang masih belum konsisten.

\section{LANDASAN TEORI DAN PENGEMBANGAN HIPOTESIS}

\subsection{AAgency Theory}

Teori keagenan (Agency Theory) menjelaskan bahwa hubungan antara agen (manajemen) dan principal (pemilik/ pemegang saham) dapat menciptakan konflik kepentingan. Pemegang saham (shareholders) akan fokus pada penciptaan return dari investasi yang telah mereka tanamkan di perusahaan berupa dividen maupun kenaikan harga saham. Agen (manajemen) akan lebih fokus pada kebijakan yang memberikan manfaat bagi manajemen. Untuk mengurangi agency cost, perusahaan membuat kontrak yang menyelaraskan insentif manajemen dengan pemegang saham (Jensen dan Meckling, 1976). Insentif yang bisa diberikan antara lain bonus bagi manajemen yang didasarkan pada laba setelah pajak. Laba setelah pajak digunakan agar manajemen fokus pada kebijakan yang dapat meminimalkan pembayaran pajak. Bonus juga dapat diberikan dalam bentuk pemberian saham perusahaan (share bonus). Kepemilikan saham oleh manajemen ini diharapkan dapat mengurangi konflik kepentingan karena manajemen juga sekaligus sebagai pemilik perusahaan sehingga diharapkan kebijakan yang diambil dapat meningkatkan penciptaan nilai bagi perusahaan.

\subsection{Praktik Penghindaran Pajak (Tax Avoidance)}

Slamet (2007) menjelaskan bahwa praktik tax avoidance dikategorikan menjadi (1) acceptable tax avoidance dan (2) unacceptable tax avoidance. Setiap negara memiliki kebijakan yang berbeda terkait penghindaran pajak yang diperbolehkan (acceptable) dan yang tidak diperbolehkan (unacceptable). Perbedaan kedua hal tersebut terletak dari motivasi atau good faith wajib pajak. Tindakan wajib pajak dikategorikan sebagai acceptable tax avoidance jika memenuhi karakteristik sebagai berikut:

a. Memiliki tujuan usaha yang baik
b. Bukan semata-mata untuk menghindari pajak


c. Sesuai dengan maksud dari pembuat undang-undang (spirit \& intention of parliament)

d. Tidak melakukan transaksi yang direkayasa

Sebaliknya, suatu tindakan disebut sebagai unacceptable tax avoidance atau aggressive tax avoidance bila memiliki ciri-ciri sebagai berikut:

a. Tidak memiliki tujuan usaha yang baik

b. Semata-mata untuk menghindari pajak

c. Tidak sesuai dengan spirit \& intention of parliament

d. Adanya transaksi yang direkayasa agar menimbulkan biaya-biaya atau kerugian.

Utomo dkk (2012) dalam artikel yang berjudul "Relationship Between Shareholders Motives and Corporate Tax Avoidance" menjelaskan bahwa pada dasarnya pelaporan keuangan dan pelaporan pajak harusnya tidak berbeda. Kedua laporan tersebut bisa berbeda bergantung pada niat atau motivasi dari si pembuat laporan yakni manajemen. Keputusan mengambil tindakan untuk menghindari pajak dibuat dapat diambil jika dirasa menguntungkan manajemen. Jika tindakan tersebut disetujui oleh pemegang saham maka manfaat dari penghindaran pajak akan diperoleh baik oleh manajemen maupun pemegang saham, misalnya melalui skema kompensasi untuk manajemen.

\subsection{Kepemilikan Manajerial}

Teori keagenan menjelaskan bahwa konflik kepentingan dapat terjadi antara pemilik dan manajemen. Perbedaan kepentingan seharusnya tidak terjadi jika manajemen juga merupakan pemilik atau pemegang saham perusahaan. Kepemilikan oleh manajemen akan membuat tujuan antara manajemen dan pemegang saham menjadi selaras. Pertimbangan lain menurut William dan
Sen (1997) yang dikutip oleh Hadi \& Mangoting (2014) menyatakan bahwa jika pemegang saham juga merupakan manajemen perusahaan, maka keputusan yang diambil manajemen dapat cenderung menjadi tidak efektif. Manajemen akan mengambil tindakan yang menimbulkan potensi dapat meningkatkan benefit bagi dirinya sebagai pemegang saham dan manajemen sehingga potensi direksi untuk melakukan penghindaran pajak meningkat.

Zhou (2011) menemukan bahwa semakin tinggi prosentase kepemilikan saham oleh manajemen dan adanya dual service yang diberikan akan berdampak pada tingkat effective tax rate yang rendah. Chan et al., (2013) dan (Multazam, 2018) juga mendukung temuan bahwa kepemilikan saham oleh manajemen memiliki pengaruh terhadap kecenderungan perilaku tax aggressiveness.

Cabello et al., (2019) dalam artikelnya yang berjudul "Tax Avoidance in Management - Owned Firms: Evidence from Brazil" menunjukkan bahwa tingkat kepemilikan saham oleh manajemen yang berbeda berhubungan dengan tingkat perilaku penghindaran pajak yang berbeda pula. Penelitian Cabello dkk ini membagi variabel kepemilikan manajerial berdasarkan prosentase kepemilikan saham manajemen. Hasil penelitian tersebut menunjukkan bahwa tingkat perilaku penghindaran pajak meningkat dalam tingkat kepemilikan manajerial dengan prosentase $20-30 \%$ dan di atas $50 \%$.

Penelitian lain oleh Fadhila et al., (2017), Boussaidi \& Hamed (2015), dan Badertscher et al., (2013) menemukan bahwa kepemilikan manajemen memiliki hubungan negatif dengan agresivitas pajak. 
Berdasarkan latar belakang dan literatur teori yang penulis sampaikan, hipotesis dibuat sebagai berikut:

\section{H1: Kepemilikan Manajerial berpengaruh Positif terhadap kecenderungan praktik penghindaran pajak}

Kerangka penelitian dibuat sebagai berikut:

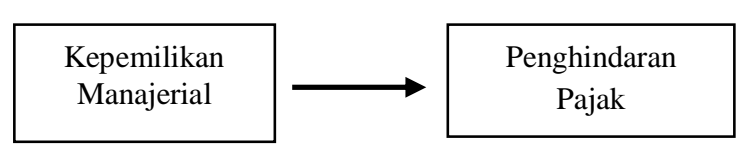

Gambar 2.1 Kerangka Penelitian

\section{METODOLOGI PENELITIAN}

Penelitian ini menguji pengaruh kepemilikan manajemen terhadap penghindaran pajak berdasarkan sampel perusahaan manufaktur yang terdaftar di bursa saham BEI selama periode 3 (tiga) tahun yakni 2015 sampai dengan 2017 . Jumlah observasi dalam penelitian ini yakni 145 observasi. Data diperoleh dari website www.idx.co.id.

Metode analisis yang digunakan dalam penelitian ini yakni analisis regresi dengan data panel tidak seimbang (unbalanced data panel) diolah dengan menggunakan aplikasi SPSS. Persamaan model dalam penelitian ini dibuat sebagai berikut:

$$
\begin{aligned}
\mathrm{ETR}_{\mathrm{it}} & =\mathrm{C}_{0}+\beta_{1} \mathrm{MO}_{\mathrm{it}}+\beta_{2} \mathrm{MO}_{\mathrm{it}}+\beta_{3} \mathrm{MO} 2_{\text {it }} \\
& +\beta_{4} \mathrm{MO}_{\mathrm{it}}+\beta_{5} \mathrm{MO}_{\text {it }}+\beta_{6} \mathrm{MO}_{\text {it }}+ \\
& \beta_{7} \mathrm{ROA}_{\mathrm{it}}+\beta_{8} \mathrm{SIZE}_{\mathrm{it}}+\beta_{9} \mathrm{LEV}_{\text {it }}+\mathrm{e}_{\mathrm{it}}
\end{aligned}
$$

$\begin{array}{ll}\text { ETR }_{\text {it }} & =\text { Effective Tax Rate } \\ \text { MO1,2,3,4,5 } & =\text { Managerial ownership } \\ \text { ROA } & =\text { Return on assets } \\ \text { SIZE } & =\text { SIZE } \\ \text { LEV } & =\text { Leverage } \\ \beta_{1-} \beta_{9} & =\text { Coefficients } \\ \text { Co } & =\text { Constanta }\end{array}$

$$
\begin{array}{ll}
\mathrm{e} & =\text { Error } \\
\text { it } & =\text { company } \mathrm{i} \text { year } \mathrm{t}
\end{array}
$$

Definisi dan pengukuran masing-masing

\begin{tabular}{|c|c|c|}
\hline $\begin{array}{c}\text { Jenis } \\
\text { Variabel }\end{array}$ & $\begin{array}{c}\text { Nama } \\
\text { Variabel }\end{array}$ & $\begin{array}{l}\text { Pengukur } \\
\text { an }\end{array}$ \\
\hline $\begin{array}{l}\text { Depende } \\
\mathrm{n}\end{array}$ & $\begin{array}{l}\text { Effective Tax } \\
\text { Rate (ETR) } \\
\text { merupakan } \\
\text { tingkat } \\
\text { pembayaran } \\
\text { pajak } \\
\text { perusahaan } \\
\text { dibandingkan } \\
\text { dengan laba } \\
\text { sebelum pajak. } \\
\text { Kecenderunga } \\
\text { n tingkat } \\
\text { penghindaran } \\
\text { pajak dapat } \\
\text { dilihat dari } \\
\text { rasio ETR yg } \\
\text { semakin rendah }\end{array}$ & $\begin{array}{l}\text { Total pajak } \\
\text { penghasila } \\
\text { n dibagi } \\
\text { laba } \\
\text { sebelum } \\
\text { pajak } \\
\text { (rasio) } \\
\text { Boussaidi } \\
\text { \& Hamed } \\
\text { (2015); } \\
\text { Cabello \& } \\
\text { Gaio } \\
\text { (2018) }\end{array}$ \\
\hline \multirow[t]{2}{*}{$\begin{array}{l}\text { Independ } \\
\text { en }\end{array}$} & $\begin{array}{l}\text { Kepemilikan } \\
\text { Manajerial } \\
\text { /Managerial } \\
\text { Ownership } \\
\text { (MO) } \\
\text { merupakan } \\
\text { tingkat/prosent } \\
\text { ase } \\
\text { kepemilikan } \\
\text { saham oleh } \\
\text { manajemen } \\
\text { dibandingkan } \\
\text { total saham } \\
\text { beredar } \\
\text { perusahaan }\end{array}$ & $\begin{array}{l}\text { Total } \\
\text { kepemilika } \\
\mathrm{n} \quad \text { saham } \\
\text { oleh } \\
\text { manajeme } \\
\mathrm{n} \text { dibagi } \\
\text { total saham } \\
\text { beredar } \\
\text { (rasio) } \\
\text { Boussaidi } \\
\text { \& Hamed } \\
\text { (2015); } \\
\text { Multazam } \\
\text { \& } \\
\text { Rahmawat } \\
\text { y (2018); } \\
\text { Cabello \& } \\
\text { Gaio } \\
\text { (2018) }\end{array}$ \\
\hline & $\begin{array}{l}\text { MO1 } \\
\text { merupakan } \\
\text { variabel } \\
\text { kepemilikan }\end{array}$ & $\begin{array}{l}\text { Dummy } \\
\text { diberi nilai } \\
1 \text { jika } \\
\text { prosentase }\end{array}$ \\
\hline
\end{tabular}
variabel dijelaskan dalam tabel 1 sebagai berikut:

Tabel 1. Definisi dan Pengukuran Variabel 


\begin{tabular}{|c|c|}
\hline \begin{tabular}{lr}
\multicolumn{2}{l}{ manajemen } \\
yang dirubah \\
ke & bentuk \\
dummy &
\end{tabular} & $\begin{array}{l}\text { kepemilika } \\
\mathrm{n} \quad \text { saham } \\
\text { manajeme } \\
\mathrm{n} \quad<10 \% \text {, } \\
\text { selain itu } \\
\text { diberi nilai } \\
0 \\
\text { Cabello \& } \\
\text { Gaio } \\
(2018)\end{array}$ \\
\hline $\begin{array}{l}\text { MO2 } \\
\text { merupakan } \\
\text { variabel } \\
\text { kepemilikan } \\
\text { manajemen } \\
\text { yang dirubah } \\
\text { ke bentuk } \\
\text { dummy }\end{array}$ & $\begin{array}{l}\text { Dummy } \\
\text { diberi nilai } \\
1 \quad \text { jika } \\
\text { prosentase } \\
\text { kepemilika } \\
\mathrm{n} \quad \text { saham } \\
\text { manajeme } \\
\mathrm{n} \\
>10 \%<20 \\
\%, \quad \text { selain } \\
\text { itu diberi } \\
\text { nilai } 0 \\
\text { Cabello \& } \\
\text { Gaio } \\
(2018)\end{array}$ \\
\hline $\begin{array}{l}\text { MO3 } \\
\text { merupakan } \\
\text { variabel } \\
\text { kepemilikan } \\
\text { manajemen } \\
\text { yang dirubah } \\
\text { ke bentuk } \\
\text { dummy }\end{array}$ & $\begin{array}{l}\text { Dummy } \\
\text { diberi nilai } \\
1 \quad \text { jika } \\
\text { prosentase } \\
\text { kepemilika } \\
\mathrm{n} \text { saham } \\
\text { manajeme } \\
\mathrm{n} \quad \\
>20 \%<30 \\
\%, \quad \text { selain } \\
\text { itu diberi } \\
\text { nilai } 0 \\
\text { Cabello \& } \\
\text { Gaio } \\
(2018)\end{array}$ \\
\hline $\begin{array}{l}\text { MO4 } \\
\text { merupakan } \\
\text { variabel } \\
\text { kepemilikan } \\
\text { manajemen } \\
\text { yang dirubah } \\
\text { ke bentuk } \\
\text { dummy }\end{array}$ & $\begin{array}{l}\text { Dummy } \\
\text { diberi nilai } \\
1 \quad \text { jika } \\
\text { prosentase } \\
\text { kepemilika } \\
\mathrm{n} \quad \text { saham } \\
\text { manajeme } \\
\mathrm{n} \quad \\
>30 \%<40 \\
\%, \quad \text { selain } \\
\text { itu diberi } \\
\text { nilai } 0\end{array}$ \\
\hline
\end{tabular}

\begin{tabular}{|c|c|c|}
\hline & & $\begin{array}{l}\text { Cabello \& } \\
\text { Gaio } \\
\text { (2018) }\end{array}$ \\
\hline & $\begin{array}{l}\text { MO5 } \\
\text { merupakan } \\
\text { variabel } \\
\text { kepemilikan } \\
\text { manajemen } \\
\text { yang dirubah } \\
\text { ke bentuk } \\
\text { dummy }\end{array}$ & $\begin{array}{l}\text { Dummy } \\
\text { diberi nilai } \\
1 \quad \text { jika } \\
\text { prosentase } \\
\text { kepemilika } \\
\mathrm{n} \text { saham } \\
\text { manajeme } \\
\mathrm{n}>50 \% \text {, } \\
\text { selain itu } \\
\text { diberi nilai } \\
0 \\
\text { Cabello \& } \\
\text { Gaio } \\
(2018)\end{array}$ \\
\hline \multirow[t]{3}{*}{ Kontrol } & $\begin{array}{l}\text { Return on Aset } \\
\text { (ROA) }\end{array}$ & $\begin{array}{l}\text { Laba } \\
\text { operasi } \\
\text { dibagi total } \\
\text { aset } \\
\text { Cabello \& } \\
\text { Gaio } \\
(2018)\end{array}$ \\
\hline & $\begin{array}{l}\text { Leverage } \\
\text { (LEV) }\end{array}$ & $\begin{array}{l}\text { Utang } \\
\text { jangka } \\
\text { Panjang } \\
\text { dibagi total } \\
\text { aset } \\
\text { Cabello \& } \\
\text { Gaio } \\
(2018) \\
\end{array}$ \\
\hline & $\begin{array}{l}\text { Firm } \\
\text { (SIZE) }\end{array}$ & $\begin{array}{l}\text { Natural log } \\
\text { total aset } \\
\text { Boussaidi } \\
\& \text { Hamed } \\
(2015)\end{array}$ \\
\hline
\end{tabular}

Kepemilikan saham manajemen dengan prosentase $>40 \%<50 \%$ tidak digunakan dalam penelitian ini karena berdasarkan sampel yang digunakan tidak ada data perusahaan dengan prosentase kepemilikan tersebut.

\section{HASIL DAN PEMBAHASAN}

Tabel 2 menyajikan hasil statistik deskriptif data yang digunakan dalam penelitian. Analisis statistik deskriptif disajikan hanya untuk variabel tax 
avoidance, managerial ownership (MO) dalam bentuk rasio, dan variabel control.

Tabel 2 Statistik Deskriptif

\begin{tabular}{|l|l|l|}
\hline Variabel & Mean & Std. Dev \\
\hline ETR $(Y)$ & 0.1845 & 0.2291 \\
\hline MO (X1) & 0.1124 & 0.1857 \\
\hline ROA (X2) & 0.0377 & 0.0809 \\
\hline SIZE $(X 3)$ & 26.3332 & 3.6383 \\
\hline LEV $($ X4) & 0.1573 & 0.1714 \\
\hline
\end{tabular}

Berdasarkan data di tabel 2, ratarata nilai variabel Effective Tax Rate, Managerial Ownership, Return on Aset, Size, serta Leverage secara berurutan sebagai berikut $0.1845,0.1124,0.0377$, 26.3332, dan 0.1573. Nilai standar deviasi variabel tersebut secara berurutan yakni 0.2291, 0.1857, 0.0809, 3.6383 dan 0.1714 .

Hasil pengujian penulis sajikan pada tabel 3. Hasil pengujian menunjukkan bahwa kepemilikan manajerial (MO) dalam bentuk rasio/prosentase memiliki pengaruh negatif terhadap effective tax rate (ETR). Hipotesis dalam penelitian ini terdukung. Hal ini berarti bahwa semakin tinggi rasio kepemilikan manajemen dalam perusahaan, maka semakin tinggi kecenderungan perusahaan untuk melakukan penghindaran pajak.

Hasil pengujian lebih lanjut untuk variabel kepemilikan manajerial dengan menggunakan dummy mengindikasikan bahwa kepemilikan manajemen dengan prosentase $<20 \%$ (MO1 dan MO2) memiliki pengaruh negatif terhadap effective tax rate (ETR). Koefisien variabel Kepemilikan Manajerial ( MO1) yakni -0.558 signifikan pada level 0.05. Koefisien variabel Kepemilikan Manajerial (MO2) yakni -0.433 signifikan pada level 0.1. Hal ini menunjukkan bahwa kecenderungan penghindaran pajak terjadi pada perusahaan dengan kepemilikan manajerial kurang dari $20 \%$. Kepemilikan manajerial $>20 \%$ tidak memiliki pengaruh terhadap kecenderungan penghindaran pajak.

Hasil uji atas variabel kontrol menunjukkan bahwa hanya variabel Return on Aset saja yang berpengaruh terhadap kecenderungan penghindaran pajak.

Tabel 3. Hasil Uji Regresi

\begin{tabular}{|c|c|c|}
\hline \multicolumn{3}{|c|}{$\begin{array}{l}\mathrm{ETR}_{\text {it }}=\mathrm{C}_{0}+\beta_{1} \mathrm{MO}_{\text {it }}+\beta_{2} \mathrm{MO}_{\text {it }}+ \\
\beta_{3} \mathrm{MO}_{\text {it }}+\beta_{4} \mathrm{MO}_{3}+\beta_{5} \mathrm{MO}_{\text {it }}+ \\
\beta_{6} \mathrm{MO}_{\text {it }}+\beta_{7} \mathrm{ROA}_{\text {it }}+\beta_{8} \mathrm{SIZE}_{\mathrm{it}}+\beta_{9} \mathrm{LEV}_{\mathrm{it}} \\
+\mathrm{e}_{\mathrm{it}}\end{array}$} \\
\hline Variable & Coefficient & t-statistic \\
\hline Constant & 0.788 & 2.654 \\
\hline MO & $-1.910 * * *$ & -2.942 \\
\hline MO1 & $-0.558 * *$ & -2.086 \\
\hline MO2 & $-0.433^{*}$ & -1.788 \\
\hline MO3 & -0.077 & -0.365 \\
\hline MO4 & 0.010 & 0.043 \\
\hline MO5 & 0.756 & 1.914 \\
\hline ROA & $0.999 * * *$ & 4.434 \\
\hline SIZE & -0.001 & -0.160 \\
\hline LEV & -0.096 & -0.884 \\
\hline Adj. $R^{2}$ & 0.165 & \\
\hline F-Statistic & $4.163 * * *$ & \\
\hline
\end{tabular}

Berdasarkan hasil uji tersebut, persamaan model dibuat sebagai berikut:

$$
\begin{aligned}
& \mathrm{ETR}_{\mathrm{it}}=0.788-1.910 \mathrm{MO}_{\mathrm{it}}-0.558 \mathrm{MO}_{\text {it }} \\
& -0.433 \mathrm{MO}_{\mathrm{it}}-0.77 \mathrm{MO}_{\text {it }}+0.010 \mathrm{MO} 4_{\text {it }} \\
& +0.756 \mathrm{MO}_{\mathrm{it}}+0.999 \mathrm{ROA}_{\mathrm{it}}- \\
& 0.001 \mathrm{SIZE}_{\mathrm{it}}-0.096 \mathrm{LEV}_{\mathrm{it}}+\mathrm{e}_{\mathrm{it}}
\end{aligned}
$$

Penelitian ini menguji pengaruh kepemilikan manajerial terhadap kecenderungan praktik penghindaran pajak oleh perusahaan. Hipotesis yang diuji dalam penelitian ini yaitu apakah kepemilikan manajerial berpengaruh positif terhadap kecenderungan praktik 
penghindaran pajak. Hasil pengujian menunjukkan bahwa kepemilikan manajerial memiliki pengaruh negatif terhadap tingkat pembayaran pajak (effective tax rate). Pengaruh negatif menunjukkan bahwa semakin tinggi kepemilikan manajemen maka tingkat pembayaran pajak (ETR) semakin rendah. Atau dengan kata lain, terdapat hubungan positif antara kepemilikan manajerial terhadap kecenderungan praktik penghindaran pajak. Lebih lanjut, penelitian ini juga menemukan bahwa perusahaan dengan kepemilikan manajemen kurang dari 20\% memiliki kecenderungan untuk melakukan praktik penghindaran pajak. Hasil penelitian ini mendukung hasil penelitian Ying (2011), Chan et al. (2013), Cabello and Gaio (2018), and Multazam and Rahmawaty (2018). Hasil penelitian menunjukkan hasil yang berbeda dengan hasil penelitian dari of Jamei (2017), Prasetyo dan Pramuka (2018), Fadhila, Pratomo, dan Yudowati (2017), Boussaidi (2015), serta Badertscher, Katz, dan Rego (2013).

Secara keseluruhan, penelitian ini memberikan kontribusi terhadap literatur penelitian penghindaran pajak dengan menunjukkan bahwa prosentase tingkat kepemilikan manajerial dapat mempengaruhi tingkat kecenderungan praktik penghindaran pajak.

Penelitian ini memiliki keterbatasan antara lain sampel dalam penelitian ini tidak dapat menguji pengaruh kepemilikan manajerial dengan prosentase kepemilikan $>40 \%<50 \%$ karena data sampel perusahaan yang digunakan tidak ada dengan karakteristik kepemilikan dengan prosentase tersebut. Keterbatasan tersebut bisa dikembangkan untuk penelitian selanjutnya dengan menambah data sampel dari industri selain manufaktur. Penelitian berikutnya juga dapat dikembangkan pengukuran penghindaran pajak selain ETR misal dengan pengukuran BTD (book tax different). (Bauer, Kourouxous, \& Krenn, 2018)

\section{REFERENSI}

Badertscher, B. A., Katz, S. P., \& Rego, S. O. (2013). The Separation of Ownership and Control and Corporate Tax Avoidance. Journal of Accounting and Economics, 228-250.

Bauer, T., \& Kourouxous, T. (2017). Taxation and Agency Conflicts Between Firm Owners and Managers: A Review. Business Research.

Boussaidi, A., \& Hamed, M. S. (2015). The Impact of Governance Mechanism on Tax Aggresiveness: $\quad$ Empirical Evidence From Tunisian Context. Journal of Asian Business Strategy, 1-12.

Cabello, O. G., Gaio, L. E., \& Watrin, C. (2019). Tax Avoidance in Management - Owned Firms: Evidence From Brazil. International Journal of Managerial Finance.

Chan, K. H., Mo, P. L., \& Zhou, A. Y. (2013). Goverment Ownership, Corporate Governance, and Tax Aggresiveness: Evidence From China. Accounting and Finance, 1029-1051.

Fadhila, N. S., Pratomo, D., \& Yudowati, S. P. (2017). Pengaruh Kepemilikan Manajerial, Komisaris Independen dan Komite Audit Terhadap Tax Avoidance. E-Jurnal Akuntansi 
Universitas Udayana, 1803 1820.

Hadi, J., \& Mangoting, Y. (2014). Pengaruh Struktur Kepemilikan dan Karakteristik Dewan Terhadap Agresivitas Pajak. Tax Accounting Review.

Jamei, R. (2017). Tax Avoidance and Corporate Governance Mechanism: Evidence from Tehran Stock Exchange. International Journal of Economics and Financial Issues, $638-644$.

Jensen, M. C., \& Meckling, W. H. (1976). Theory of The Firm: Managerial Behavior, Agency Cost and Ownership Structure. Journal of Financial Economics, $305-360$.

Multazam, S., \& Rahmawaty. (2018). The Influence of Leverage, Executive Incentives, Managerial Ownership on Tax Aggresiveness (Study in Manufacturing Companies listed on IDX Year 2012 - 2014). Jurnal Ilmiah Mahasiswa Ekonomi Akuntansi, 494 - 504.

Prasetyo, I., \& Pramuka, A. B. (2018). Pengaruh Kepemilikan Institusional, Kepemilikan Manajerial, dan Proporsi Dewan Komisaris Independen Terhadap Tax Avoidance. Jurnal Ekonomi, Bisnis, dan Akuntansi.

Slamet, Indrayagus. (2007). Tax Planning, Tax Avoidance, dan Tax Evasion di Mata Perpajakan Indonesia. Inside Tax, Edisi Perkenalan.
Utomo, S., Palil, M. R., Jaffar, R., \& Ramli, R. (2012). Relationship Between Shareholders Motives and Corporate Tax Avoidance: A Literature Study. International Journal of Business, Economics, and Law, 2289 - 1552.

Ying, Z. (2011). Ownership Structure, Board Characteristics, and Tax Aggresiveness. Lingnan University, China. 